\title{
THE INFLUENCE OF
}

SMALL BUSINESS SUPPORT SYSTEMS ON ECONOMIC DEVELOPMENT: A CASE STUDY IN LESOTHO

\author{
John Masten $^{*}$ and Donovan Russell ${ }^{\star \star}$
}

\section{INTRODUCTION}

The vital role of small business in maintaining a nation's economic health has only recently been fully recognized by U.S. policy makers. United States employment statistics indicate that the small business sector (firms with fewer than 100 employees) created many of new jobs from 1980 to $1982[7, \mathrm{p} .1]$. The value of a thriving small business sector in promoting economic development has also been underemphasized by government planners and donor agencies in Lesotho. The brisk pace and obvious expansion of this sector in Lesotho are causing policymakers to reassess small business needs and government programs.

The value of small business as an economic development tool has been actively debated in economic growth literature for many years. Rostow [6] noted that small and medium sized industry create most of a nation's new jobs during periods of rapid growth. More recently arguments for small business as a generator of exports and jobs in Third World countries have been advanced.

Petrof [5, p.52] noted that small business can make a positive contribution to economic development if potential buyers and sellers are brought together, relevant market information is communicated, resources are efficiently used, demand stimulated for products with a high domestic and export growth potential and small firms are dispersed throughout a country. Since less developed countries lack markets necessary to support mass production and do not have sophisticated technology and infrastructure, small business may be the appropriate production and distribution vehicle $[2, \mathrm{p} .19]$. Small firms may find it easier to create a market niche, producer products with less technology and be more adaptable. Cobbe $[1, p .152]$ recognized early on the need for

\footnotetext{
${ }^{*}$ Professor, Dean, School of Business, Tennessee State University, Nashville, Tennessee.

${ }^{* *}$ Professor, Chief of Projects, Institute for Extramural Studies, National University of Lesotho, Lesotho, Africa.
} 
small scale, dispersed rural industry in Lesotho to provide income earning opportunities and to make use of underemployed labour.

More recently, studies conducted by the German Institute and USAID/Lesotho [3] found that small craft industries which do not rely on foreign skills, technology or capital can be suitable instruments to generate employment $^{1}$. The Institute also suggested that small craftsmen and traders in Lesotho could become larger and more successful businessmen with; proper assistance.

This paper summarizes the current economic environment in Lesotho and discusses future income and employment prospects. The support systems (parastatals) for business creation that are financed by government and private donors will be reviewed. Suggestions are made to improve job creation efforts by parastatals.

\section{THE LESOTHO ECONOMIC ENVIRONMENT}

The high percentage of workers employed outside Lesotho and the disproportionate share of gross national product (GNP) generated from this activity make Lesotho's economy unique. The primary source of GNP and the country's geographic location seriously distort private enterprise development. The paucity of reliable data on income, employment, number and type of firms make economic analysis and policy formulation difficult. Economic data from the World Bank's 1983 Economic Memorandum on Lesotho and information from interviews with ministerial officials will be used as a base in this paper [8].

Lesotho, a country about the size of Maryland with a population estimated in 1982 at 1.4 million, is designated by the United Nations as one of the least developed countries in the world. Per capita income in 1980-81 was estimated to be $\$ 190$ [8]. The Republic of South Africa (RSA) which totally surrounds Lesotho is a technically advanced country. However, it has racial policies which are unacceptable to Lesotho. Unfortunately, Lesotho is exceedingly economically dependent on the RSA. The dependence is obvious (i.e.,migrant labourers, shopkeepers and customs revenues).

In 1976 the Lesotho labour force was estimated to be 426,000 . Thirty-one and a half percent of 134,500 Basotho (as residents of Lesotho are called) were employed (primarily in mines) in the $\mathrm{RSA}^{2}$. This figure represented about $50 \%$ of the male labour force. Remittances to Basotho miners accounted for $40.5 \%$ of GNP and $68.3 \%$ of gross domestic product (GDP) in 1981- 82. Due to rapid wage increases for miners, remittances since

1 An up-to-date unpublished report on the status of the small business sector is available at the Lesotho USAID Office.

2 See [8]. 
1970 have grown at an average annual rate of $12.6 \%$ while GDP has grown briskly at $7.3 \%$. In 1976 only $4.9 \%$ of the labour force within Lesotho, 16,900 , was considered employed in industry. Government employment accounted for $17 \%$ while agriculture accounted for $40.9 \%$ or 174,300 . In 1976, labour which was not identified as mining, industry or services was thought to be in agriculture. Unfortunately, since reliable data on the size of the informal and trade sector did not exist, employment in business activity was understated. Employment in agriculture, then, was probably overstated.

Other than the rapid growth in miners' remittances, the increase in GDP in Lesotho is from increased South African Customs Unions revenues, large increase in external assistance, and expanded diamond output ${ }^{3}$. The growth in GNP has not translated into local jobs, especially in new basic industries. Private consumption expenditures have increased to a level that exceeded GDP in 1982. Simultaneously, government expenditures doubled while gross investment actually fell from $\$ 35.9$ million to $\$ 24.8$ million. Since consumer goods were not available locally, the increased consumption was in imports from the RSA. Presently RSA imports represent about $75 \%$ of total consumption expenditures.

Unfortunately, the rapid growth in Lesotho which occurred during the 70s may not continue. Basotho employment in the mines may gradually decline. Thus, the income from miner remittances may decline even with continuing increases in miner wages. Gross National Product from this course will eventually fall. Further, revenues from the customs unions have stagnated. The only Government diamond mine has recently closed and donor contributions have peaked. Without expansion of basic industry in Lesotho growth GNP will decline. With a population growth rate of $2.3 \%$, a sharp increase in unemployment will almost certainly occur.

\section{EFFORTS TO INCREASE JOB OPPORTUNITIES IN LESOTHO}

The Third Five Year Plan for the Kingdom of Lesotho, published in 1979 , called for "a reduction in the country's vulnerability to external economic and political pressure through sustained economic growth, diversification of investment and economic activity, and considerably increased domestic employment with greater emphasis on labourintensive techniques" [4, p.2].

Commercial bank lending in 1978 was concentrated on consumption, and short term financing of wholesale and retail trade. But, Government planners argued that these sectors could not form the basis for strong

3 The SACU comprises the RSA, Botswana, Lesotho and Swaziland. The Union's purpose is to promote trade among the members and present a common tariff policy. The agreement calls for a common revenue pool which consists of customs, excise, sales and other related duties collected in the customs area. Lesotho's share is determined by formula. 
industrial development ${ }^{4}$. Government policy and country resources were to be directed toward creating domestic employment in basic industries to reduce dependency on employment opportunities in South Africa. These basic industries would concentrate on export and import substitution activities.

The goal of developing basic industries presented a difficult challenge, given the numerous constraints on Lesotho economic activity. These constraints were not limited to finances. They included a lack of economic and physical infrastructure, limited profitable investment opportunities (considering the small size of the domestic market) and the general uncertainty about future economic and political development in South Africa.

In 1978 there were apparently 40 manufacturing firms located in Lesotho. These firms employed approximately 7,500 people. Also some 9,000 were employed in construction and approximately 7,500 were working in wholesale and retail trade 5 . When compared to a labour force of over 450,000 , employment in these sectors was quite insignificant.

The magnitude of the problem is further illustrated when one compares the number of new jobs that must be created annually for new male entrants into the labour force, with existing employment in manufacturing. Presently 10,000 jobs must be created annually just to employ new male entrants. The creation of 10,000 new jobs annually would be a difficult task under the most optimal circumstances.

Government investment in industrial and commercial ventures, as well as the promotion of private investment, utilizing two parastatals, has been the basis of the industrial job creation plan. The two parastatals are the Lesotho National Development Corporation (LNDC) and the Basotho Enterprise Development Corporation (BEDCO). Training of workers and entrepreneurs is supported through at least three other agencies.

Table 1 provides a list of government and quasi-government support agencies in Lesotho whose efforts are directed toward influencing employment and economic efficiency. For each agency the primary client served (Column 4), and an estimate of the sector's overall growth since 1978 (Column 6), are listed.

\section{RESULTS OF JOB CREATION EFFORTS}

Like many underdeveloped African countries economic development opportunities depend on stimulating foreign investment, expanding exports, and creating more import substituting industries. Not-

\footnotetext{
4 Ibid pg. 120.

5 Ibid pg. 326.
} 
withstanding economic inhibitors to development such as market size, poor transportation and communication systems, restraining licensing and regulatory requirements, support agencies can play a causal role in the development process. In Lesotho, parastatal services include reducing business "start up" costs and risk sharing. Employee and entrepreneur training can reduce business failures in both new and existing enterprises.

Current employment statistics are not available to assess the success of the Government Five Year Plan to increase employment basic industries. However, by interviewing key personnel in the parastatals and comparing trade license data between 1978 and 1983, success of the most recent Five Year Plan and the agencies themselves can be evaluated ${ }^{6}$. As listed in Column 3 of Table 1, except for training, the job creation results of the parastatals from 1978-1982 have been poor.

\section{PROFILE OF GOVERNMENT POLICY IMPACT ON BUSINESS DEVELOPMENT IN LESOTHO 1978-1983}

LNDC was organized to manage direct government investment and to encourage foreign investors to set up primarily export businesses which would employ ten or more people. Firms which employ 10 or more employees are considered large. The provision of serviceable industrial sites and buildings, guaranteed loans, and general country assistance for foreign investors formed the basis of LNDC services. The Pioneer Industries Encouragement Act granted tax holidays and other incentives. This Act is utilized in LNDC's promotional efforts to attract foreign investors.

New basic businesses with 10 or more employees are provided buildings in industrial estates and receive both employee training and belowmarket loans. LNDC also has authority to own and manage business enterprise. Currently its owns shares in 18 firms, nine of which are equity positions of less than $50 \%$. An additional 13 firms have loans from the agency. Approximately 3,350 workers are employed in the 31 firms. In the next two years, LNDC plans to create 3,500 new jobs far below the estimated 10,000 needed. An import substitution committee has been established to conduct research and disseminate findings on products which might be successfully produced in Lesotho, which are not imported from the RSA. As listed in Table 1, Column 3, no new net jobs have been created since 1978 from LNDC efforts. Program failure during the period is attributed difficulties of government-owned enterprises and increased competition from the "homelands" being created by South Africa. Generous concessions are given to foreign investors who locate firms in homeland areas. Job availability is an economic incentive utilized by RSA to induce black people to remain in designated areas [9, p.60]. Lesotho-made products, however, can be sold tariff-free in

6 Data for this section was obtained from high ranking officials interviewed from the Ministry of Trade and Tourism, BEDCO, and LNDC. 
Common Market countries. The ability to export to other Black African states as well as to the RSA is a positive attraction for locating in Lesotho.

The unsuccessful record of government-owned and managed large business has caused LNDC to reorganize it efforts. It now concentrates exclusively on providing industrial building sites and loan to private industries. Generally, sponsored firms from outside have created few linking relationships with local enterprises. LNDC incentive services have benefited foreign investors rather than the local Basotho entrepreneur.

Although the LNDC has not been successful in generating net new employment over the past five years, half of all existing employment in basic industry large firms can be attributed to past LNDC efforts. In spite of the various barriers such as market size, structured constraints, regulatory inhibitors, etc., LNDC must increase job creation productivity for employment to grow in this sector.

BEDCO is the Lesotho. Government's small business assistance division (less than 10 employees). It directs efforts toward developing local entrepreneurs and establishing small business. Rental workshop space, guaranteed loans, marketing, and training assistance are provided. Most of the assistance is directed toward basic industries located in the capital city, Maseru. Loans, training, site rentals, and individualized consulting are the major services. Currently, BEDCO has over 200 loans to firms which collectively employ some 1,000 workers. Although the loan failure rate is high, officials optimistically estimate that 126 net new jobs were created each year since 1978. Essentially the limitations of BEDCO programs have centered on the quality of services, a limited service network beyond the capital city, and inability to identify and develop highly promising entrepreneurs.

The government also sponsors business training programs. The Business Training Center, a jointly sponsored program of the University and Government, of fers trader training classes through the country, utilizing not only University personnel, but 10 government-employed Extension Officers. When offered, these programs are well attended by local businessmen. The Lesotho Opportunities Industrialization Center (LOIC), a Maseru-basic vocational skills training program, and BEDCO also offer retail management training courses in Maseru. All three programs are financed by the government and employ full time teaching staff. Economic development may be promoted through improvement of the basic business skills of existing owners and managers and those who plan to enter business in the future. Unfortunately, the duplication of seminar courses by support training agencies merely increases government inefficiency in promoting nationwide economic development.

There are other groups offering training courses, e.g., the International Labour Organization (ILO) sponsors two small entrepreneur training classes each year for returning migrant labourers who wish to remain in 
Lesotho. About 50 persons are served through this effort. Training classes are also provided for government employees through a group called the Institute for Development Administration (IDA). No programs or support services are presently available for developing and improving the efficiency of the informal sector except for a few self help groups such as small cooperative enterprises. The exact size of this sector is unknown but the sector is quite large. As listed in Column 3 and Figure 1, about 1,000 individuals from the wholesale, retail and government sectors receive training each year from the agencies' combined efforts. Generally, the resource commitment for small business development is second in priority to foreign industrial efforts. Except for trader training, local wholesale and retail trade is not included in government efforts to develop entrepreneurial skills or small business as alternatives to large enterprise development.

In the last column of Table 1, estimates as to the overall employment growth of the sectors, regardless of parastatal efforts since the development of the Five Year Plan, are presented. Unfortunately, no employment data exists to substantiate these estimates except of ficial records from the Office of Pioneer Industries (OPI), World Bank data, and interviews with government officials. Records from OPI indicate that 79 firms with 10 or more employees existed in 1984, representing a growth of 1,000 new jobs since 1981. Candid discussions, however, with Ministry of Trade and Tourism and LNDC personnel reflect a different picture. They claim that no new net jobs were created during the period. Their observations are verified by the 1982 decline in the percentage of manufacturing contribution to the GDP, as indicated by World Bank figures.

The small industries sector seems to have moderately increased during the period. BEDCO has generated about 750 new jobs although this operation is primarily confined to the capital city of Maseru. Trader licenses which cost 100 Maloti (Lesotho currency), have risen at a rate of 1,000 per year since 1978. Currently there are approximately 11,500 issued. This compares with 7,000 in 1978. If this data is correct, the basic small business and retail trade sectors enjoy by far the most rapid growth. Government employment has also expanded during the planning period. Information on employment changes in the informal sector is not available.

Improved efficiency in job creation activities by parastatals will be necessary for overall employment growth in the large and small basic industry sectors to occur and if entrepreneurs are to redirect their meager resources to the basic industry sector. Currently parastatals employ over 75 staff members. Individual job creation costs for LNDC are estimated to be $16,000 \mathrm{M}$ per year. BEDCO job creation costs range between 2,000 and 3,000 $\mathrm{M}$ per year.

Lesotho can be summarized as an economy which has experienced rapid growth during the five-year planning period. This growth has increased 
personal income and thus personal consumption expenditures. The additional goods and services consumed by Basotho have come mainly from RSA firms, causing imports to be a very high percentage of GNP. Rapid growth generated by gifts and minor wages is not expected to continue. The latest Five Year Plan attempted to redirect resources in the government sector toward job creation in basic industries. Emphasis was placed on export and import substituting activities. The effort has been notable but the economy has not been redirected. The unsupported sector, retail trade, is where most of the business expansion has occurred. This sector will stabilize and possibly decline as current external inputs decline. This will further compound unemployment problems.

\section{REDIRECTING POLICY TO INCREASE JOB OPPORTUNITIES}

Given the magnitude of the nation's reliance on the RSA for economic survival, increased effectiveness in job creation will only marginally solve the employment problem. Several policy changes are suggested which might increase the efficiency of this effort and reduce the per job creation cost. Over the past five years growth in private employment in Lesotho has come from the unassisted retail sector through expansion of wholesale and retail outlets. Parastatals' contribution to job and basic industry creation has been poor. Government policymakers may need to consider terminating ineffective parastatals and reallocating revenue to other worthy endeavors. If support of parastatal programs are to be continued, performance may be improved by initiating new activities. These activities include (1) the development of a process to identify highly promising Basotho entrepreneurs, (2) the redirection of existing support services to the village level to create local businesses, (3) the improvement of coordination among support agencies, (4) the utilization of new approaches for inducing private investors to locate in Lesotho for the purpose of producing products for exports, and (5) the emphasis of potential linking relationships as a criteria for LNDC assistance.

Given the paucity of individuals with entrepreneurial skills in Lesotho, those who have successful started and developed retail businesses must be encouraged to participate in government efforts to redirect business activity to basic industries. Business Extension Officers already in place seem to be natural links to identifying and directing these successful entrepreneurs to the appropriate support agency. Easy loan access and one-on-one technical/managerial support can then be provided to those who can be classified as highly promising.

Current data can be gathered which categorizes village expenditures by product and total amount spent. A further classification of village products by basic need, appropriate technology, and source of product indicates there is a wealth of small business opportunity in the villages. 
The information on purchase habits could be matched with potential village entrepreneurs. Government agencies could then assist these entrepreneurs through training and loans. Presently easily available venture capital is only possible for those who have significant collateral. Most of these people are in the capital city.

Centralizing small and large business support services may be a solution to coordination problems, since new business ideas coming from the import substitution committee in LNDC do not filter down to small business agencies. District level business Extension Officers are not provided information on new business possibilities for their districts and are unaware of the process which businesses must follow to use BEDCO services. A unified approach could reduce the overlap of current services and require fewer government employees. To the extent that personnel costs are reduced or more new firms established, the cost per job created will decline.

Attracting foreign investors on economic grounds may overlook Lesotho's main asset. This asset is the country's disadvantaged status and helpless reliance on the racially restrictive RSA. Presenting this picture in a positive manner, especially in western countries, may attract private investors for philanthropic motives. Currently over forty donor agencies are operating in Lesotho. It would seem that private investors could also be attracted to Lesotho even if the return on investment were a little lower than in other locations. To illustrate, in the United States the private sector is searching for ways to assist the disadvantaged in Third World Countries. Creating jobs by guaranteeing purchase of output or finding ways in which Lesotho firms could be organized to assemble pre-developed components may be feasible.

Needless to say, Lesotho does not have much time to expand its basic industries before additional unemployment begins. The efficient utilization of existing resources by parastatals is essential and ethically necessary in the developmental process. By taking steps to increase efficiency in government services, Lesotho will be given an encouraging signal to both external and internal potential investors. 


\section{REFERENCES}

[1] Cobbe, J.H. "Growth and Change in Lesotho", in The South African Journal of Economics. 46.2, 1978.

[2] Dawson, L. "Opportunities for Small Business" in Third World Markets, American Journal of Small Business, Vol. VII, No. 1, July/September, 1982.

[3] Crafts and Small-Scale Industries in Lesotho: An Empirical Study of Problems and Promotion, German Development Institute, Berlin, July, 1982.

[4] Kingdom of Lesotho, Third Five Year Plan, Vol. I. Maseru Central Planning and Development Office, July, 1979.

[5] Petrof, J. "Small Business and Economic Development: The Case for Government Intervention", 2, Journal of Small Business Management. 18:51-6, 1980.

[6] Rostow, W.W. The Stages of Economic Growth. Cambridge University Press, Cambridge, Massachusetts, 1960.

[7] The State of Small Business: A Report of the President. United States Government Printing Office, Washington, D.C., 1984.

[8] Economic Memorandum on Lesotho. World Bank, Eastern Africa Regional Office, October, 1983.

[9] Ziller, H. "Restructuring the Industrial Decentralization Strategy", in South Africa Review, 1973. 


\section{SELECTED INDEX}

Administration 156

Agriculture $15,16,39,46$, $75-77,93,102,103,115,133$, 134,152

Aid $12,18,20-23,45,48,86$, $88,96-101,117,122,123$, $125-127,129,131,132,133$

Aid agencies 98,132

Aid policy 21,132

Antigua 43, 51

Antilles 5, 36, 44, 101

Bahamas 30, 41, 51

Bahrain 51, 118, 119

Barbados 6, 18, 22, 30, 41, 51

Basic needs 65, 101

Belize 4

Bermuda 41

Cape Verde $30,41,51$

Caribbean 8, 12, 17, 19, 20, 37, $66,100-104$

Central Bank 66, 116, 117, 141

Chenery 5, 9-11

Comoros 30, 41, 44, 51

Competitiveness $136,138,140$, 149

Consumption 3

Cyprus 40, 41, 43, 51

Demas 8, 10, 12, 66, 103, 104

Dominica 41, 51

EC $19,24,124,126,132,148$

Education 17, 20, 22, 47, 65, $78,79,83,84,96,103,109$, 114,131

EEZ 42

Employment 43, 59, 77, 79, 96, $108-110,125,130,136-139$, $142,145,147,148,150-157$

Environment $6,8,17,22,26$, $32,35,36,40,74,93,98,103$, $107,109,112,117,131,151$

Exchange rate $60,136,138$, $142-145,147,148$

Export 45, 46, 142, 149

Exports 134
Fiji $41,43,44,51,83,92,95$, $97,99,123,126$

Finance institutions 92

Finland 68, 136, 138, 141

Fishery 110

Food 18, 45, 79, 124, 125, 128

Food imports $19,48,123-125,130$

Foreign trade 136

French Polynesia 43, 44, 126

Gambia 30

Grenada 8, 41, 51, 100, 101

Guam 43, 44, 126

Guyana 18,101

Health care 65,131

Human rights 101

Iceland 30,40

Import $61,88,122,124,125$, $128,129,134$

Jalan $6,8,10-12,26,66$

Kiribati 4, 41, 44, 126

Kuwait 112-117, 119, 120

Labour 5, 29, 31, 46, 64, 74-76, $79,106,114,116,117,119$, $134,136,137,138,139$, $142-146,148,149,151-153$, 155

Lesotho 86, 150-159

Luxemburg 118, 119

Maldives 40, 41, 51, 106-111

Malta $28,30,33,36,40,41,51$, $87,119,120,142,143$, 146-149

Mauritius 19, 41, 43, 51

Monetary policy $57,62-65$

New Caledonia 41, 43, 87, 126

New Guinea 126

Niue 41,126 
Pacific $5,6,8,13,39,44$, $92-94,96,97,99,126,128$, 134

Polynesia $39,128,133$

Population 3-8, 10, 11, 15-17, $23,25,30,40,42,43,45,46$, $49-51,56,57,60,62,65,68$, $75,77,79,83-85,92-94,96$, $98,101-103,106,107,108$, $112-115,120,124,128,130$, $131,134,151,152$

Populations 119

Sao Tome 4, 41, 51

Selwyn 6, 7, 13, 37, 66

Seychelles 41, 43, 44, 51

Small business 150, 155-159

Solomon Islands 51, 92, 96, 98, 126

South Pacific 8, 19, 83, 84, 92, $93,95,98,99,123,124$, $126-128,131,133$

St. Lucia 18, 41, 51

St. Vincent 41, 51

St. Kitts 51

Suriname $30,66,101$

Tourism 16, 18, 22, 24, 46, 100, $106-108,110,156$

Trinidad $40,41,43,51$

Tuvalu 4, 41, 44, 96, 99

Unemployment $57,64,110$, $136,139,141,152,157,158$

Vanuatu 84

Viability 4, 12, 39, 40, 45, 48, $50,60,94,112-115,117-120$

Wallis 126

Welfare $30,37,67,102,110$, 116

Western Pacific 17

Western Samoa 18, 51, 92, 94, $122,123,125,126,128-134$ 



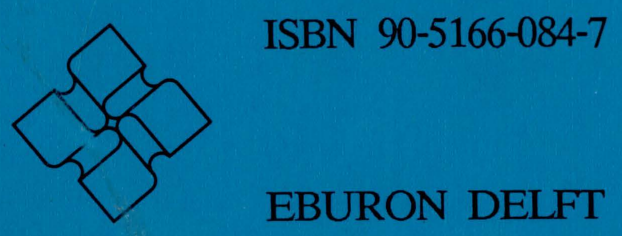

